\title{
DESENTRALISASI PENDIDIKAN DAN PERAN AKTIF MASYARAKAT MENUUJU PENDIDIKAN BERKUALITAS
}

\author{
Nur Ervannudin dan Bimo Wahyu Widodo \\ Universitas Negeri Surakarta, Jawa Tengah, Indonesia \\ ervan14.ed@gmail.com
}

\begin{abstract}
EDUCATION DECENTRALISATION AND ACTIVE SOCIETIE'S ROLE TOWARD QUALITY EDUCATION. Education is the key for a country to win the competition in today's era. The era of globalization has had implications for all aspects of our lives. Both positive and negative impacts. The positive impact of these developments such as the implementation of democracy in our country. The democratic system automatically make decentralization as a way to run this system. Decentralization as an attempt delegation of authority from superiors to subordinates to achieve a common goal.Decentralization of education to make officials and actors in the region have the authority to regulate and manage their own their own potential. However, there are many things that keep pace with the development of this run. As well as the opportunities, challenges, obstacles and the active role of society towards quality education. Opportunities that looks real is the potential of what we have. Such as buman resource potential is quite large. These opportunities coupled with the implementation of MEAs in the year 2016. ME $A$ becomes the arena for success not only in our country alone, but without success on the international arena area. As for the obstacles that lurk is the readiness of all elements of education in this country in the face of these challenges. However, we need not fear because we had something different from other nations. Community
\end{abstract}


participation into something different and distinctive for the nation of Indonesia.

Key Word: Decentralization, Education, Quality

\begin{abstract}
Abstrak
Pendidikan adalah kunci bagi suatu negara untuk memenangkan persaingan di era sekarang ini. Era globalisasi membawa dampak bagi segala lini kehidupan kita. Dampak positif maupun dampak negatif. Dampak positif dari perkembangan ini seperti terlaksananya demokrasi di negara kita. Sistem demokrasi dengan otomatis menjadikan desentralisasi sebagai jalan untuk menjalankan sistem ini. Desentralisasi sebagai upaya pelimpahan wewenang dari atasan kepada bawahan untuk mencapai tujuan bersama. Desentralisasi pendidikan menjadikan pejabat dan pelaku di daerah memiliki wewenang untuke mengatur dan mengelola sendiri potensinya sendiri. Namun demikian ada banyak hal yang mengikuti dengan perkembangan yang dijalankan ini. Seperti halnya peluang, tantangan, hambatan serta peran aktif masyarakat untuk menuju pendidikan yang berkualitas. Peluang yang terlihat nyata adalah potensi dari apa yang kita miliki. Seperti potensi sumber daya manusia yang cukup besar. Peluang ini ditambah dengan diberlakukannya MEA pada tabun 2016 ini. MEA menjadi arena untuk meraih kesuksesan bukan hanya di negara kita saja tetapi meraih sukses pada kancah kawasan internasional. Adapun hambatan yang mengintai adalah kesiapan segenap elemen pendidikan di negara ini dalam menghadapi tantangan ini. Namun demikian kita tidak perlu takut karena kita punya sesuatu yang berbeda dari bangsa lain. Peran serta masyarakat menjadi sesuatu yang berbeda dan khas bagi bangsa indonesia.
\end{abstract}

Kata Kunci : Desentralisasi, Pendidikan, Kualitas.

\title{
A. Pendahuluan
}

Pendidikan merupakan nyawa dari sebuah peradaban suatu bangsa. Pendidikan menjadi hal yang sangat perlu diperhatikan oleh semua pihak yang menginginkan keteraturan dalam kehidupannya. Setiap orang berpendidikan tentu akan memiliki nilai tambah dibanding dengan orang yang belum berpendidikan. 
Pendidikan menekankan kepada perubahan perilaku fisik maupun nonfisik dari manusia tersebut.

Setiap negara di dunia berusaha sekuat tenaga untuk selalu melakukan continous Improvement dalam dunia pendidikan. Hal ini dikarenakan semua negara meyakini kunci sukses meraih masa depan adalah sukses di dunia pendidikan. Banyak hal yang bisa dilakukan untuk selalu memperbaiki sistem pendidikan. Pendidikan diyakini menjadi kunci sukses karena dengan melalui pendidikan suatu negara dapat mendesain akan diseperti apakan generasi penerusnya?. Sebagai manusia dengan kecakapan hidup yang seperti apa?, manusia yang bersikap bagaimana, kesemuanya dicapai dengan jalan pendidikan.

Kebijakan pendidikan selalu dipengaruhi dari berbagai hal. Antara lain seperti sejarah bangsa, ekonomi, budaya, dan global trend. Sejarah sebuah bangsa memengaruhi kebijakan karena sebuah bangsa berdiri atas kumpulan peristiwa penting masa lalu, seperti halnya indonesia memiliki sejarah perjuangan dalam memperjuangkan kemerdekaan sehingga kebijakan pendidikanpun juga tidak lepas dari nilai historis perjuangan. Dalam bidang ekonomipun sangat kentara nuansanya, pendidikan menjadi jalan sertifikasi bagi para pencari pekerjaan. Sehingga kebijakanpun juga selalu berhubungan dengan kondisi ekonomi sebuah bangsa, orientasi hasil pendidikan akan dijadikan seorang leader market atau hanya sebatas tenaga kerja kasar saja. Budaya menjadi ruh dari sebuah pendidikan karena budayalah yang menjadi orientasi keluruhan sebuah bangsa. Apalagi indonesia sebagai bangsa timur yang menjunjung tinggi kesopan sikap dalam kehidupan dan tata sopan norma dan nilai. Kebijakan pendidikan selalu berlandaskan budaya bangsa yang luhur karena memang pendidikan juga sebagai alat pelestari budaya. Yang terakhir adalah global trend, hal ini menjadi hal yang wajar di era globalisasi seperti saat ini. Trend di dunia seperti apa maka pemegang kekuasaan pembuat kebijakan harus selalu mengikuti dan menyesuaikan. Sehingga kebijakan yang dijalankan dapat menjawab tantangan kedepan. 
Dimulai semenjak Indonesia mulai memasuki era reformasi semua lini sendi birokrasi di Indonesia juga tidak luput dari reformasi. Dari dulu yang kesemua lini bernafaskan sentralistik sedikit demi sedikit bergeser pada paradigma desentralistik. Demikian juga yang terjadi pada sistem pendidikan kita yang juga memaksa diri untuk mengikuti era desentralisasi. Pelimpahan wewenang untuk mengatur sistem sesuai dengan kondisi daerah masisng-masing. Proses ini membutuhkan waktu yang tidak sebentar untuk melihat hasil perkembangannya.

Desentralisasi solah menjadi angin segar bagi semua pihak yang selama masa sentralistik serasa dibelenggu daya kreatifitasnya. Banyak pihak yang semangat dan menatap dengan kecerahan wajah penuh antusias. Tak terlewatkan dalam dunia pendidikan, juga merasa demikian mulai dari pemerintah daerah sampai satuan tingkat pendidikan di grass root.

Proses desentralisasi menuai harapan bagi semua pihak yang terlibat langsung maupun tidak langsung. Nafas partisipasi dari berbagai pihak untuk kesuksesan bersama menghipnotis dan mengamini perkembangan ini. Dari pihak penyelenggara diberi wewenang untuk mengatur wilayah kekuasaannya. Selebihnya masyarakat diberi hak dan diberi kesempatan aktif untuk ikut berpartisipasi dalam penyelenggaraan proses pendidikan. Selain itu masyarakat juga berhak mengontrol dan mengawasi proses yang berlangsung.

Peluang di negara berkembang seperti Indonesia memiliki potensi yang sangat luar biasa. Dependenty Ratio Indonesia diperkirakan pada 2020 mencapai 70\%. Artinya adalah 70\% masyarakat Indonesia adalah manusia produktif. Sangat wajar dan penting apabila pendidikan harus segera bersiap ibarat gayung bersambut akan masa depan. Dengan usia produktif yang sangat tinggi tersebut membuka peluan bagi kaum pendidik mendesain pendidikan yang dapat menjawab tantangan. Adapun yang disiapkan adalah semua lini tidak hanya parsial saja. 
Dampak era globalisasi adalah akan diberlakukannya MEA (Masyrakat Ekonomi Asean). Yang pada hal ini mau atau tidak kita harus menghadapi pasar bebas di asean. Yang pada konkretnya kita diadu dengan masyarakat dari berbagai negara di asean. Siap atau tidak siap akan melewati fase itu. Hal ini menjadi angin segar dan harapan dengan sekarung potensi dari bonus yang sudah kita miliki. Kita akan menjadi pemimpin dan pemegang kuasa di negara kita sendiri. Hal ini karena kita memiliki segalanya baik dari SDM atau SDA.

Dari potensi yang ada yang bersumber dari bonus demografi kita patut berbangga dan percaya diri. Karena begitu besarnya potensi dan ketersediaan momen untuk menyalurkannya. Rasanya kita tidak sabar menunggu dibukannya kran dan meraih masa depan yang menggembirakan ini. Dengan menjadi leader di kawasan Asean kita mendapatkan angin segar untuk kesejahteraan bagi kita semua.

Namun seolah kita terlena dengan euphoria kesegaran desentralisasi dan harapan segar dari bonus demografi. Kita mengabaikan persiapan yang harus kita siapakan. Banyak hal yang masih mendera jantung sistem pendidikan kita. Mulai dari kurikulum yang masih kalang kabut sampai infrastruktur dan kuranganya pemeraatan akses pendidikan.

Banyak data kita ketahui sejak 15 tahun kita berdesentralisasi namun belum sampai titik puncak kejayaan dari cita-cita. HDI kita juga belum signifikan menunjukkan perkembangannya. Tata kelola desentralisasi juga belum maksimalkan dijalankan stake holder yang terkait. Peran serta masyarakat juga belum menunjukkan partisipasi aktif.

Ibarat kata kita masih di kegelapan sistem, tentu kita tidak boleh menggelapakan sesuatu yang sudah gelap. Sebaiknya kita menerangi kegelapan tersebut walaupun dengan sebuah lilin. Ketika kita bersama-sama maka kegelapan akan mencadi cerah terang dan menerangi. Kita tetap harus optimis bahwa kita bisa memanfaatkan semua potensi yang kita miliki. 
Wadah sistem desentralisasi harus menjadi kawah candra dimuka bagi persiapan dalam menghadapi tantangan kedepan. Kita harus mampu memanfaatkan sistem ini dengan seoptimal mungkin. Potensi peluang berwujud bonus demografi juga harus diurus dan digarap secara matang demi memenangkan pertarungan yang sudah ada di depan mata.

Ketika bangsa di sekitar kita sudah mulai bergegas memasuki wilayah kita, terbesit pertanyaan sampai seberapa siap kita mengahadapinya. Menjadi penonton di negeri sendiri atau bercita-cita besar menjadi mercusuar di kawasan Asean dengan segala potensi yang kita miliki. Kita tetap harus menjaga asa menjadi bangsa leader dan berdiri tegak diatas keluhuran dan keagungan local wisdom.

\section{B. Pembahasan}

\section{Konsep Desentralisasi Pendidikan}

Otonomi daerah sebagai salah satu bentuk desentralisasi pemerintahan, pada hakikatnya ditujukan untuk memenuhi kepentingan bangsa secara keseluruhan, yaitu upaya untuk lebih mendekati tujuan-tujuan penyelenggaraan pemerintahan untuk mewujudkan cita-cita masyarakat yang lebih baik, suatu masyarakat yang lebih adil dan lebih sejahtera.

Desentralisasi diartikan sebagai penyerahan wewenang pemerintahan oleh pemerintah kepada daerah otonom untuk mengatur dan mengurus urusan pemerintahan dalam sistem Negara Kesatuan Republik Indonesia (pasal 1 ayat (7) UU Nomor 32 Tahun 2004). Menurut Hasbullah dalam buku otonomi pendidikan, desentralisasi adalah suatu proses dimana suatu lembaga yang lebih rendah kedudukannya menerima pelimpahan kewenangan untuk melaksanakan segala tugas pelaksanaan pendidikan, termasuk pemanfaatna segala pasilitas yang ada serta penyusunan kebijakan dan pembiayaan 
Tentang desentralisasi ini ada beberapa konsep yang dikemukakan oleh para ahli sebagai berikut: ${ }^{1}$

a. Desentralisasi merupakan penyerahan wewenang dari tingkat pemerintahan yang lebih tinggi kepada pemerintah yang lebih redah, baik yang menyangkut bidang legislatif, judikatif, atau administratif.

b. Desentralisasi menurut Soejanto adalah sebagai suatu sistem yang dipakai dalam bidang pemerintahan merupakan kebalikan dari sentralisasi, dimana sebagai kewenangan pemerintah pusat dilimpahkan kepada pihak lain untuk dilaksanakan.

c. Mardiasmo mengartikan Desentralisasi tidak hanya berarti pelimpahan wewenang dari pemerintah pusat ke pemerintah yang lebih rendah, tetapi juga pelimpahan beberapa wewenang pemerintahan ke pihak swasta dalam bentuk privatisasi.

d. Hogerwert memberikan definisi Desentralisasi adalah sebagai pengakuan atau penyerahan wewenang oleh badanbadan umum yang lebih rendah untuk secara mandiri dan berdasarkan pertimbangan kepentingan sendiri mengambil keputusan pengaturan pemerintahan, serta struktur wewenang yang terjadi dari hal itu.

e. Pengertian desentralisasi koswara pada dasarnya mempunyai makna bahwa melalui proses desentralisasi urusan-urusan pemerintahan yang semula termasuk wewenang dan tanggung jawab pemerintah pusat sebagaian diserahkan kepada pemerintah daerah agar menjadi urusan rumah tangga sehingga urusan tersebut beralih kepada dan menjadi wewenang dan tanggung jawab pemerintah daerah.

f. Desentralisasi atau mendesentralisasi pemerintahan bisa berarti merestrukturisasikan atau mengatur kembali kekuasaan sehingga terdapat suatu sistem tanggung jawab bersama antara intitusi-institusi pemerintah tingkat pusat,

\footnotetext{
${ }^{1}$ Ibid., hlm. 76-85.
} 
regional, maupun lokal sesuai dengan prinsip subsidiaritas. Sehingga meningkatkan kualitas keefektifan yang menyeluruh dari sistem pemerintahan, dan juga meningkatkan otoritas dan kapasitas tingkat subnasional.

Dari beberapa konsep diatas dapat disimpulkan bahwa desentralisasi merupakan adanya penyerahan wewenang urusan yang semula menjadi kewenangan pemerintah pusat kepada pemerintah daerah untuk melaksanakan urusan-urusan tersebut.

Kewenangan pengelolaan pendidikan berubah dari sistem sentralisasi kesistem desentralisasi. Desentralisasi pendidikan berarti terjadinya pelimpahan kekuasaan dan wewenang yang lebih luas kepada daerah untuk membuat perencanaan dan mengambil keputusannya sendiri dalam mengatasi permasalahan yang dihadapi pendidikan. ${ }^{2}$

Berdasarkan PP Nomor 25 Tahun 2000 tentang kewenangan pemerintah dan kewenangan provinsi sebagai daerah Otonom, pada kelompok bidang pendidikan dan kebudayaan disebutkan bahwa kewenangan pemerintah meliputi hal-hal sebagai berikut:

a. Penetapan standar kompetensi siswa dan warga belajar, serta pengaturan kurikulum nasional dan penilaian hasil belajar secara nasional, serta pedoman pelaksanaannya.

b. Penetapan standar materi pelajaran.

c. Penetapan persyaratan perolehan dan penggunaan gelar akademik.

d. Penetapan pedoman pembiayaan penyelenggaraan pendidikan

e. Penetapan persyaratan penerimaan, pemindahan, sertifikasi siswa, warga belajar dan mahasiswa.

Sementara itu, kewenangan pemerintah provinsi meliputi hal-hal sebagai berikut:

${ }^{2}$ Sam Chan, Analisis SWOT: Kebijakan Pendidikan Era Otonomi Daerah. (Jakarta: PT. Raja Grafindo Persada, 2005), hlm. 78. 
a. Penetapan kebijakan tentang penerimaan siswa dan mahasiswa dari masyarakat minoritas, terbelakang, dan atau tidak mampu.

b. Penyediaan bantuan pengadaan buku pelajaran pokok/ modul penidikan untuk taman kanak-kanak, pendidikan dasar, pendidikan menengah, dan pendidikan luar sekolah.

c. Mendukung/membantu penyelenggaraan pendidikan tingi selain pengaturan kurikulum, akreditasi, dan pengangkatan tenaga akademis.

d. Pertimbangan pembukaan dan penutupan perguruan tinggi

e. Penyelenggaraan sekolah luar biasa dan balai pelatihan dan atau penataran guru

f. Penyelenggaraan museum provinsi, suaka peninggalan sejarah, kepurbakalaan, kajian sejarah dan nilai tradisional, serta pengembangan bahasa dan budaya daerah.

Desentralisasi pendidikan merupakan sebuah sistem manajemen untuk mewujudkan pembangunan pendidikan yang menekankan pada kebhinnekaan. Menurut Santoso S. Hamijoyo dalam buku otonomi pendidikan, ada beberapa hal yang harus dipenuhi dalam pelaksanaan desentralisasi pendidikan, yaitu: ${ }^{3}$

a. Pola dan pelaksanaan manajemen harus demokratis

b. Pemberdayaan masyarakat harus menjadi tujuan utama

c. Peranserta masyarakat harus menjadi tujuan utama

d. Peranserta masyarakat bukan hanya pada stakeholders, tetapi harus menjadi bagian mutlak dari sistem pengelolaan

e. Pelayanan harus lebih cepat, efisien, efektif, melebihi pelayanan erasentralisasi demi kepentingan peserta didik dan rakyat banyak

${ }^{3}$ Hasbullah, Otonomi Pendidikan, hlm. 78. 
f. Keaneka ragaman aspirasi dan nilai serta norma lokal harus dihargai dalam kerangka dan demi penguatan sistem pendidik nasional.

Dalam praktiknya, desentralisasi pendidikan berbeda dengan desentralisasi bidang pemerintahan lainnya, kalau desentralisasi bidang-bidang pemerintahan lain berada pada pemerintahan di tingkat kabupaten/kota, maka desentralisasi dibidang pendidikan tidak berhenti pada tingkat kabupaten/ kota, tetapi justru sampai pada lembaga pendidikan atau sekolah sebagai ujung tombak pelaksanaan pendidikan. Dalam praktik desentralisasi pendidikan itulah maka dikembangkanlah yang dinamakan Manajemen Berbasis Sekolah (MBS).

MBS Berpotensi menawarkan partisipasi masyarakat, pemeranataan, efisiensi, serta manajemen yang bertumpu pada tingkat sekolah. MBS Berfungsi untuk menjamin bahwa semakin rendahnya kontrol pemerintah pusat, tetapi semakin meningkatnya otonomi sekolah untuk menentukan sendiri apa yang perlu diajarkan dan mengelola sumber daya yang ada disekolah untuk berinovasi dan berimprovisasi.

\section{Peluang, Tantangan dan Hambatan Pendidikan}

\section{a. Bonus Demografi}

Peningkatan ranking Indeks Pembangunan Manusia (IPM/ HDI) negara Indonesia dari ranking 121 pada tahun 2012 menjadi ranking 108 pada tahun 2013 merupakan kabar menggembirakan bagi bangsa. Namun, jika mencermati posisi ranking negaranegara terdekat seperti Malaysia yang mengalami kenaikan dari ranking 64 ke ranking 62, Singapura dari ranking 18 ke ranking 9, Brunei Darussalam pada ranking yang sama yaitu 30, dan China dari ranking 101 ke ranking 91 (UNDP 2013, UNDP 2014), maka posisi HDI Indonesia masih perlu ditingkatkan agar posisinya tidak terlalu jauh dari posisi negara-negara tetangga. Agar dapat menduduki posisi yang lebih baik diperlukan kerja keras untuk memperbaiki kualitas manusia Indonesia, meningkatkan daya 
saing bangsa, di tengah-tengah persaingan dengan masyarakat dunia lainnya.

Ini semua merupakan pekerjaan rumah seluruh rakyat Indonesia. Indeks Pembangunan Manusia (IPM) atau Human Development Index (HDI) merupakan pengukuran perbandingan dari harapan hidup, melek huruf, pendidikan dan standar hidup untuk semua negara seluruh dunia. IPM digunakan untuk mengklasifikasikan apakah sebuah negara adalah negara maju, negara berkembang atau negara terbelakang dan juga untuk mengukur pengaruh dari kebijaksanaan ekonomi terhadap kualitas hidup. Mengingat bahwa salah satu indikator dari IPM adalah sektor pendidikan, maka para pelaku pendidikan, khususnya pendidikan ekonomi, mempunyai tugas yang tidaklah ringan untuk dapat mengembangkan pendidikan ekonomi yang mampu mendukung pertumbuhan ekonomi Indonesia. Pendidikan ekonomi dapat memfasilitasi kebutuhan masyarakat terhadap pengetahuan ekonomi dan keuangan yang sangat diperlukan pada masa ekonomi global yang sedang dihadapi masyarakat dunia saat ini.

Untuk menghadapi era globalisasi, SDM yang mampu bersaing mutlak diperlukan. Hampir semua pakar ketenagakerjaan setuju bahwa kunci sukses suatu organisasi adalah SDM yang memiliki kompetensi kerja. Oleh karenanya, sebagai upaya peningkatan kualitas SDM yang berasal dari lulusan pendidikan tinggi, sangatlah berhubungan dengan pengembangan berbagai ketrampilan yang relevan (generic skills), sehingga dengan semakin meningkatnya kompetensi lulusan diharapkan dapat memenuhi keragaman permintaan pasar kerja era globalisasi. Sebagai institusi di bawah LPTK, pendidikan ekonomi mendapat mandat untuk menghasilkan guru yang memiliki kompetensi spesifik yang dibutuhkan untuk melaksanakan tugas atau pekerjaan, yang beragam sesuai dengan keragaman aktivitas dan dapat dikembangkan selama proses pembelajaran berlangsung. ${ }^{4}$

${ }^{4}$ Fuad Nurhattati, Manajemen Pendidikan Berbasis Masyarakat Konsep dan 
Selanjutnya muncul pertanyaan, bagaimana cara melaksanakan pendidikan ekonomi yang mampu meningkatkan generic skills mahasiswa pendidikan ekonomi. hal yang dapat dilakukan adalah melalui pengembangan materi-materi pembelajaran yang dapat mengakomodasi peningkatan generic skills, atau melalui internalisasi nilai-nilai generic skills pada setiap program yang dilakukan secara kontinyu yang terjabar dalam kurikulum. ${ }^{5}$ Kurikulum merupakan "seperangkat rencana dan pengaturan mengenai tujuan, isi dan bahan pelajaran serta cara yang digunakan sebagai pedoman penyelenggaraan kegiatan pembelajaran mencapai tujuan pendidikan tertentu". ${ }^{6}$

Agar dapat mencapai tujuan pendidikan menghasilkan guru yang mampu melaksanakan pendidikan ekonomi, maka kurikulum pendidikan ekonomi dapat didesain dengan muatan mata kuliah, pengalaman belajar dan perencanaan pembelajaran ekonomi sedemikian rupa. Perlu diperhatikan juga bahwa generic skills sangat penting untuk dimiliki oleh lulusan Pendidikan Ekonomi pada khususnya, dan semua mahasiswa pada umumnya. ${ }^{7} \mathrm{Hal}$ ini sesuai dengan pendapat dari Satoshi bahwa "Generic skills are important for higher education graduates in their employment, successful competition in labor market, development of career in organization and bringing individual input in the successful development of democratic society. Developed generic skills ensure broader person's social security and possibilities for selfrealization."

Strategi Implementasi, (Depok: RajaGrafindo, 2014), hlm 56.

${ }^{5}$ Ali Imron, Kebijaksanaan Pendidikan di Indonesia. (Malang: Bumi Aksara, 1993), hlm, 34.

${ }^{6}$ UU RI Nomor 20 Tahun 2013, mengenai tentang pendidikan dan yang berkecimpung dalam dunia pendidikan.

${ }^{7}$ Gunawan Sudarmanto. Pembiayaan Pendidikan Dan Otonomi Sekolah Dalam Menghadapi Globalisasi. Seminar Internasional tentang Globalisasi Pendidikan yangdiselenggarakan oleh Program Pascasarjana FKIP Universitas Lampung, bertempat di Balai KeratunJl. Wolter Monginsidi, Badnar Lampung tanggal 21 Juni 2010

${ }^{8}$ Suroso, Jarot S.. Pendidikan Nasional di Indonesia. (Siapkah Menghadapi 
Dengan demikian, ketika suatu negara menginginkan kualitas sumber daya manusia, khususnya calon pendidik, yang mampu bersaing maka negara tersebut dapat mengawalinya melalui pembangunan generic skills bagi bangsanya. Oleh karena itu, peran LPTK sangatlah besar. Artikel ini bertujuan untuk menawarkan suatu strategi integrasi pengembangan generic skills dalam kurikulum pendidikan ekonomi. 'Kurikulum merupakan cetak biru dari keseluruhan proses pembelajaran pada sistem pendidikan. Melalui kurikulum dapat diketahui arah semua aktivitas pendidikan Indonesian Qualifications Framework dalam mencapai tujuan pendidikan yaitu pengembangan manusia yang memiliki pengetahuan, keterampilan, teknologi serta karakter sesuai dengan falsafah hidup bangsa dan penciri institusi pendidikan di mana mereka belajar. Oleh karena itu, suatu institusi pendidikan dituntut mampu mendesain kurikulum sesuai dengan kebutuhan dan perkembangan masyarakat serta perkembangan kemajuan ilmu pengetahuan, teknologi, seni dan olah raga (IPTEKSO).

Kurikulum pendidikan tinggi saat ini mengalami pembaharuan dalam konsep kurikulum, sebagaimana dalam buku pedoman penyusunan kurikulum berbasis kompetensi dari Dirjen Pendidikan Tinggi. Beberapa pembaharuan konsep kurikulum antara lain: 1) Luaran hasil pendidikan tinggi yang semula berupa kemampuan minimal penguasaan pengetahuan, ketrampilan, dan sikap sesuai dengan sasaran kurikulum suatu Program studi, diganti dengan kompetensi seseorang untuk dapat melakukan seperangkat tindakan cerdas, penuh tanggungjawab sebagai syarat untuk dianggap mampu oleh masyarakat dalam melaksanakan tugas-tugas di bidang pekerjaan tertentu. ${ }^{9}$ Pendidikan tinggi ini yang semula penilaiannya dilakukan oleh penyelenggara

Globalisasi?). (Online). http://www.scribd.com/doc/6480664/Globalisasi- Pendidikan

${ }^{9}$ Ali Imron, 1993. Kebijaksanaan Pendidikan di Indonesia. (Malang: Bumi Aksara, 1993), hlm. 54. 
pendidikan tinggi sendiri, dalam konsep yang baru penilaian selain oleh perguruan tinggi juga dilakukan oleh masyarakat pemangku kepentingan. 2) Kurikulum program studi yang semula disusun dan ditetapkan oleh Pemerintah lewat sebuah Konsorsium (Kurikulum Nasional), diubah, yakni kurikulum inti disusun oleh perguruan tinggi bersama-sama dengan pemangku kepentingan dan kalangan profesi, dan ditetapkan oleh perguruan tinggi yang bersangkutan. 3) Berdasarkan Kepmendikbud No. 056/ U/1994 komponen kurikulum tersusun atas Kurikulum Nasional (Kurnas) dan Kurikulum Lokal (Kurlok) yang disusun dengan tujuan untuk menguasai isi ilmu pengetahuan dan penerapannya (content based), sedangkan dalam Kepmendiknas No. 232/ U/2000 disebutkan bahwa kurikulum terdiri atas Kurikulum Inti dan kurikulum Institusional. ${ }^{10}$

Dalam Kepmendiknas no 232/U/2000, hasil belajar ditekankan pada keutuhan kompetensi berkarya, sehingga matakuliah dikelompokkan ke dalam Matakuliah Pengembangan Kepribadian (MPK), Matakuliah Keilmuan dan Keterampilan (MKK), Matakuliah Perilaku Berkarya (MPB), Matakuliah Keahlian Berkarya (MKB), dan Matakuliah Berkehidupan Bermasyarakat (MBB). Melalui kurikulum tersebut, suatu program studi mengantar mahasiswanya memiliki kompetensi utama, kompetensi pendukung, dan kompetensi lain yang bersifat khusus dan gayut dengan kompetensi utama. Setiap kompetensi dapat mengandung 5 elemen kompetensi yaitu landasan kepribadian, penguasaan IPTEKSO, kemampuan berkarya, sikap dan perilaku dalam berkarya, dan pemahaman kaidah berkehidupan bermasyarakat.

\section{b. Globalisasi}

Perlu disadari bersama bahwa globalisasi bukanlah merupakan suatu proses alami melainkan suatu proses yang dimunculkan berdasarkan gagasan, yang selanjutnya ditawarkan

${ }^{10}$ Ibid., hlm. 65. 
kepada dunia untuk diikuti oleh bangsa lain. Dengan demikian, globalisasi yang telah menghasilkan kesepakatan bersama sangat syarat dengan muatan kepentingan dan keuntungan bagi yang menciptakan. Proses globalisasi yang telah berlangsung pada semua bidang kehidupan (seperti bidang ideologi, politik, ekonomi, sosiologi, kebudayaan pertahanan keamanan, politik internasional dan lain-lain) akan memberikan dampak negatif pada negara-negara yang tidak memiliki jatidiri yang jelas. Adanya globalisasi sudah barang tentu akan memunculkan negaranegara sebagai subyek dan objek yang masing-masing perannya sangat berbeda. ${ }^{11}$

Banyak gejala lain, globalisasi ditandai oleh ambivalensi yaitu tampak sebagai «berkah» di satu sisi tetapi sekaligus menjadi «kutukan» di sisi lain. Tampak sebagai 9 «kegembiraan» pada satu pihak tetapi sekaligus menjadi «kepedihan» di pihak lainnya. Ciri ambivalensi seperti ini dalam globalisasi adalah persoalan sentral yang maha penting. Di situ terletak locus problematicus yang menyimpan tantangan besar bagi pendidikan sekolah. Globalisasi sering diterjemahkan "mendunia" atau "mensejagat". Sesuatu entitas, betapapun kecilnya, disampaikan oleh siapapun, dimanapun dan kapanpun, dengan cepat menyebar ke seluruh pelosok dunia, baik berupa ide, gagasan, data, informasi, produksi, temuan obat-obatan, pembangunan, pemberontakan, sabotase, dan sebagainya; begitu disampaikan, saat itu pula diketahui oleh semua orang di seluruh dunia. Hal ini biasanya banyak terjadi di lingkungan politik, bisnis, atau perdagangan, dan berpeluang mampu mengubah kebiasaan, tradisi, dan bahkan budaya

Pengertian globalisasi yang umum ditemukan dalam literatur. Kelima kategori definisi tersebut berkaitan satu sama

${ }^{11}$ Rohadi Wicaksono, Dunia Pendidikan Di Era Global, (t.k: t.p,2008). Disampaikan pada acara Talk Show yang diadakan oleh Akademi Analis Farmasi dan Makanan. 
lain dan kadangkala saling tumpang-tindih, namun masing-masing mengandung unsur khas yang dapat dikemukakan sbb. ${ }^{12}$

1) Globalisasi sebagai internasionalisasi Globalisasi dipandang sebagai sebuah kata sifat (adjective) untuk menggambarkan hubungan antar-batas dari berbagai negara. Ia menggambarkan pertumbuhan dalam pertukaran dan interdependensi internasional. Semakin besar volume perdagangan dan investasi modal, maka ekonomi antar-negara semakin terintegrasi menuju ekonomi global di mana ekonomi nasional yang distingtif dilepas dan diartikulasikan kembali ke dalam suatu sistem melalui proses dan kesepakatan internasional.

2) Globalisasi sebagai liberalisasi Dalam pengertian ini, globalisasi merujuk pada sebuah proses penghapusan hambatan-hambatan yang dibuat oleh pemerintah terhadap mobilitas antar negara untuk menciptakan sebuah ekonomi dunia yang terbuka dan tanpabatas. Mereka yang berpendapat pentingnya menghapus hambatan-hambatan 10 perdagangan dan kontrol modal biasanya berlindung di balik mantel globalisasi.

3) Globalisasi sebagai universalisasi Dalam konsep ini, kata global digunakan dengan pemahaman bahwa proses mendunia dan globalisasi merupakan proses penyebaran berbagai obyek dan pengalaman kepada semua orang ke seluruh penjuru dunia. Contoh klasik dari konsep ini adalah penyebaran teknologi komputer, televisi, internet, dll.

4) Globalisasi sebagai westernisasi atau modernisasi (lebih dalam bentuk yang Americanised) Globalisasi dalam konteks ini dipahami sebagai sebuah dinamika, di mana strukturstruktur sosial modernitas (kapitalisme, rasionalisme, industrialisme, birokratisme, dsb.) disebarkan ke seluruh

${ }^{12}$ Jarot S. Suroso, Pendidikan Nasional di Indonesia. (Siapkah Menghadapi Globalisasi?). (Online). http://www.scribd.com/doc/6480664/Globalisasi-Pendidikan. 
penjuru dunia, yang dalam prosesnya cenderung merusak budaya setempat yang telah mapan serta merampas hak self-determination rakyat setempat.

5) Globalisasi sebagai penghapusan batas-batas teritorial (atau sebagai persebaran supra-teritorialitas) Globalisasi mendorong rekonfigurasi geografis, sehingga ruang-sosial tidak lagi semata dipetakan dengan kawasan teritorial, jarak teritorial, dan batasbatas teritorial. Dalam konteks ini, globalisasi juga dipahami sebagai sebuah proses (atau serangkaian proses) yang melahirkan sebuah transformasi dalam spatial organisation dari hubungan sosial dan transaksi-ditinjau dari segi ekstensitas, intensitas, kecepatan dan dampaknya-yang memutar mobilitas antar-benua atau antar-regional serta jejaringan aktivitas.

Dengan demikian, adanya globalisasi yang sudah berlangsung sangat berpengaruh terhadap semua aspek kehidupan, baik secara individu, kelompok, maupun Negara yang sudah barang tentu termasuk Indonesia. Globalisasi yang berdampak pada berbagai bidang kehidupan tersebut tentu saja berpengaruh terhadap dunia pendidikan di Indonesia. Globalisasi ini didorong oleh hiruk-pikuknya tiga faktor utama yang berupa (1) teknologi informasi, (2) uang, dan (3) manajemen sehingga 11 memiliki power untuk menggerakkan proses globalisasi keseluruh dunia (Gaffar, 2004).

\section{c. MEA (Masyarakat Ekonomi Asean)}

Konsep Masyarakat Ekonomi ASEAN Sejalan dengan pesatnya dinamika hubungan antar-bangsa di berbagai kawasan, ASEAN menyadari pentingnya integrasi negara-negara di Asia Tenggara. Pada pertemuan informal para Kepala Negara ASEAN di Kuala Lumpur tanggal 15 Desember 1997 disepakati ASEAN Vision 2020 yang kemudian ditindaklanjuti dengan pertemuan di Hanoi yang menghasilkan Hanoi Plan of Action (HPA). Visi 2020 termasuk HPA berisi antara lain: kondisi yang ingin diwujudkan 
di beberapa bidang, seperti orientasi ke luar, hidup berdampingan secara damai dan menciptakan perdamian internasional.

Beberapa agenda kegiatan yang akan dilaksanakan untuk merealisasikan Visi 2020 adalah dengan meningkatkan kualitas sumber daya manusia, ekonomi, lingkungan hidup, sosial, teknologi, hak cipta intelektual, keamanan dan perdamaian, serta turisme melalui serangkaian aksi bersama dalam bentuk hubungan kerjasama yang baik dan saling menguntungkan diantara negaranegara anggota ASEAN.

Selanjutnya pada KT'T ASEAN ke 9 di Bali pada tahun 2003 dihasilkan Bali Concord II, yang menyepakati pembentukan ASEAN Community untuk mempererat integrasi ASEAN. Terdapat tiga komunitas dalam ASEAN Community yang disesuaikan dengan tiga pilar didalam ASEAN Vision 2020, yaitu pada bidang keamanan politik (ASEAN Political-Security Community), ekonomi (ASEAN Economic Community), dan sosial budaya (ASEAN SocioCulture Community). MEA adalah tujuan akhir integrasi ekonomi seperti yang dicanangkan dalam ASEAN Vision 2020, adalah : «To create a stable, prosperous and bighly competitive ASEAN economic goods, services, investment, skill labour economic development and reduced poverty and socio-economic disparities in year 2020.»

Untuk membantu tercapainya integrasi ekonomi ASEAN melalui AEC, maka dibuatlah AEC Blueprint yang memuat empat pilar utama yaitu (1) ASEAN sebagai pasar tunggal dan berbasis produksi tunggal yang didukung dengan elemen aliran bebas barang, jasa, investasi, tenaga kerja terdidik dan aliran modal yang lebih bebas; (2) ASEAN sebagai kawasan dengan daya saing ekonomi tinggi, dengan elemen peraturan kompetisi, perlindungan konsumen, hak atas kekayaan intelektual, pengembangan infrastruktur, perpajakan, dan e-commerce; (3) ASEAN sebagai kawasan dengan pengembangan ekonomi yang merata dengan elemen pengembangan usaha kecil dan menengah, dan prakarsa integrasi ASEAN untuk negara-negara Kamboja, Myanmar, Laos, dan Vietnam; dan (4) ASEAN sebagai 
kawasan yang terintegrasi secara penuh dengan perekonomian global dengan elemen pendekatan yang koheren dalam hubungan ekonomi di luar kawasan, dan meningkatkan peran serta dalam jejaring produksi global.

Dengan berlakunya MEA 2015, berarti negara-negara ASEAN menyepakati perwujudan integrasi ekonomi kawasan yang penerapannya mengacu pada ASEAN Economic Community (AEC) Blueprint. AEC Blueprint merupakan pedoman bagi negaranegara Anggota ASEAN dalam mewujudkan AEC 2015.

Berbicara posisi Indonesia guna menyambut era perdagangan bebas ASEAN di ke-12 sektor yang telah disepakati, Indonesia telah melahirkan regulasi penting yaitu UU No 7 Tahun 2014 tentang Perdagangan yang telah diperkenalkan ke masyarakat sebagai salah satu strategi Indonesia membendung membanjirnya produk impor masuk ke Indonesia. UU ini antara lain mengatur ketentuan umum tentang perijinan bagi pelaku usaha yang terlibat dalam kegiatan perdagangan agar menggunakan bahasa Indonesia didalam pelabelan, dan peningkatan penggunaan produk dalam negeri. Melalui UU ini pula pemerintah diwajibkan mengendalikan ketersediaan bahan kebutuhan pokok bagi seluruh wilayah Indonesia. Kemudian menentukan larangan atau pembatasan barang dan jasa untuk kepentingan nasional misalnya untuk melindungi keamanan nasional.

Regulasi tersebut terasa penting bila mempertimbangkan kondisi perdagangan Indonesia selama ini belum optimal memanfaatkan potensi pasar ASEAN. Pada periode JanuariAgustus 2013 misalnya, ekspor Indonesia ke pasar ASEAN baru mencapai $23 \%$ dari nilai total ekspor Hal ini antara lain karena tujuan ekspor Indonesia masih terfokus pada pasar tradisional seperti Amerika Serikat, Tiongkok dan Jepang. Tingkat utilitisasi preferensi tarif ASEAN yang digunakan eksportir Indonesia untuk penetrasi ke pasar ASEAN baru mencapai 34,4\%. Peringkat Indonesia menurut Global Competitivenes Index masih berada pada posisi ke-38 dari 148 negara. Sementara Singapura 
menempati posisi ke 2, Malaysia di posisi ke 24, Thailand di posisi 37, Vietnam ke 70 dan Filipina di posisi 59.

Ketatnya persaingan di pasar ASEAN lebih jauh dapat disimak dari kinerja perdagangan Indonesia di tahun 2014. Sampai bulan Maret 2014, transaksi perdagangan Indonesia surplus hingga 673,2 juta dolar AS. Surplus didapat dari selisih antara nilai ekspor yang mencapai 15,21 miliar dengan impor 14,54 miliar dolar AS. Surplus Maret ini adalah yang kedua setelah bulan Februari sebesar 843,4 juta dolar AS. Namun demikian, Indonesia perlu memberi perhatian khusus terhadap transaksi dagang dengan Thailand yang akan bersama-sama terlibat dalam MEA 2015. Pada Maret 2014 dengan Thailand sampai 1,048 miliar dolar AS.

Lebih jauh lagi, surplus perdagangan Indonesia pada bulan 2014 ini belum mencerminkan kekuatan struktur ekspor Indonesia. Industri pengolahan produk ekspor masih bergantung pada bahan baku impor. Kondisi ini sangat rentan karena berarti Indonesia sangat bergantung pada ketersediaan baku dunia. Karena itu arah kebijakan ekonomi Indonesia mulai tahun 2015 harus lebih jelas seiring dengan berlakunya pasar bebas ASEAN.

Karenanya, menghadapi MEA 2015, Indonesia masih mempunyai berbagai pekerjaan rumah yang harus ditingkatkan agar tetap mempunyai daya saing. Untuk pilar sosial budaya, Indonesia masih perlu kerja keras mengingat masih banyak warga Indonesia yang belum mengetahui tentang ASEAN. Padahal salah satu kunci keberhasilan MEA adalah konektivitas atau kontak antara satu warga negara dengan warga negara ASEAN lainnya. Pemahaman warga negara di Asia Tenggara terhadap MEA belum sampai 80 persen. Karena itu, sosialisasi MEA menjadi sangat penting terhadap seluruh warga negara Indonesia yang memiliki jumlah penduduk terbesar di ASEAN. Kekuatiran yang muncul adalah, Indonesia hanya akan menjadi pasar bagi produk sejenis dari negara ASEAN lainnya. 
Untuk pilar ekonomi, Indonesia juga masih harus meningkatkan daya produk Indonesia. Indonesia masih harus mengembangkan industri yang berbasis nilai tambah. Oleh karena itu Indonesia perlu kerja keras melakukan hilirisasi produk. Dari sisi hulu, Indonesia sudah menjadi produsen yang dapat diandalkan mulai dari pertanian, kelautan dan perkebunan. Tetapi semua produk tersebut belum sampai ke hilir untuk mengurangi inpor barang jadi, sebab Indonesia telah memiliki bahan baku yang cukup.

Dari sisi liberalisasi perdagangan, produk Indonesia praktis tidak terlalu menghadapi masalah sebab hampir 80 persen perdagangan Indonesia sudah bebas hambatan. Bahkan ekonomi yang berbasis kerakyatan (UMKM) berpeluang menembus pasar negara ASEAN. Pemerintah telah melakukan upaya percepatan pemerataan pembangunan sebagai bagian dari penguatan ekonomi kerakyatan. Antara tahun 2011- 2013, investasi Indonesia banyak diarahkan pada wilayah-wilayah di luar pulau Jawa dengan memberikan rangsangan tax holiday. Dengan demikian, pusat pertumbuhan ekonomi di masa depan bukan hanya terpusat di Jawa saja tetapi juga di luar Jawa. Usaha lain yang dilakukan pemerintah adalah dengan membentuk kluster untuk pembinaan UMKM agar memiliki daya saing.

Bukan hanya tantangan yang akan dihadapi tetapi juga peluang. Sektor-sektor yang akan menjadi unggulan Indonesia dalam MEA 2015 adalah Sumber Daya Alam (SDA), Informasi Teknologi, dan Ekonomi Kreatif. Ketiga sektor ini merupakan sektor terkuat Indonesia jika dibandingkan dengan negara-negara ASEAN yang lain. Selain itu, dampak masuknya Tenaga Kerja Asing (TKA) ke Indonesia harus dipastikan bisa berbahasa Indonesia yang baik dan benar.

Menurut Direktur Eksekutif Center of Reform on Economics (CORE) Hendri Saparini, kesiapan Indonesia dalam menghadapi MEA 2015 baru mencapai 82 persen. Hal itu ditengarai dari empat (4) isu penting yang perlu segera diantisipasi pemerintah 
dalam menghadapi MEA 2015, yaitu: 1) Indonesia berpotensi sekedar pemasok energi dan bahan baku bagi industrilasasi di kawasan ASEAN, sehingga manfaat yang diperoleh dari kekayaan neraca perdagangan barang Indonesia yang saat ini paling besar di antara negara-negara ASEAN semakin bertambah, 2) melebarkan perdagangan barang, 3) membebaskan aliran tenaga kerja sehingga Indonesia harus mengantisipasi dengan menyiapkan strategi karena potensi membanjirnya Tenaga Kerja Asing (TKA), dan 4) masuknya investasi ke Indonesia dari dalam dan luar ASEAN.

Dengan demikian didalam perdagangan bebas akan ada hal positif dan negatif yang akan dialami setiap negara yang terlibat didalamnya. Tantangan bagi Indonesia kedepan adalah memwujudkan perubahan bagi masyarakatnya agar siap menghadapi.

\section{Menggesa Pendidikan World Class Berbasis Masyarakat}

Dalam penyelenggaraan program atau kegiatab apapun tentu harus dimulai dengan perencanaan. Tidak terkecuali dengan kegiatan pendidikan berbasis masyarakat. Perencanaan menjadi pijakan dalam melaksanakan berbagai kegiatan selanjutnya. Harus rapi dan detail dalam mempersiapkannya sehingga dalam pelaksanaan tidak ada kebingungan harus dijalankan seperti apa.

Seperti pada spektrum makro, Melvile Branch dan Ira M dalam Fuad mengatakan:

Suatu proses sengaja, terorganisasi, dan sinambung mengidentifikasi unsur-unsur dan aspek-aspek sebuah organisme, menentukan keadaan dan interaksi sekarang, memperkirakannya dalam waktu tertentu yang akan datang keseluruhan, serta merumuskan dan memprogramkan serangkaian rencana dantindakan untuk mencapai hasil yang diharapkan.

Perencanaan merupakan suatu proses kegiatan yang berlangsung tanpa henti, karena pada suatu saat kegiatan sudah selesai, maka kegiatan harus dilanjutkan dengan kegiatan-kegiatan berikutnya., sehingga membentuk siklus kegiatan yang tertata 
dengan rapi. Penyusunan rencana dilakukan secara berurutan sesuai ketentuan, walau langkah dan urutannya menurut ahli yang satu dengan yang lain berbeda.

A.W.P Guruge dalam mengemukakan secara garis besar proses perencanaan dilakukan ke dalam tahap: a) praperencanaan; b) perencanaan; c)Formulasi perencanaan; d) Elaborasi perencanaan ; e) Pelaksanaan perencanaan; f) Evaluasi, revisi dan perencanaan ulang. Sedangkan Udin dalam merincikan perencanaan ke dalam kegiatan berikut:

a. Analisis kebutuhan

b. Formulasi tujuan dan sasaran

c. Penentuan dan penekanan kebijakan serta prioritas

d. Rumusan program dan kegiatan

e. Pengujian tingkat kelayakan

f. Pelaksanaan rencana

g. Penilaian dan umpan balik untuk perencanaan selanjutnya

Sehingga dapat kita simpulkan bahwa semua kegiatan harus direncanakan dengan baik dengan mempertimbangkan beberapa faktor yang mungkin mempengaruhi. Yang dimaksud perencanaan disini adalah persiapan pemrogaman kedepan dengan berbagai analisis. Dalam merencanakan harus digunakan analisis kebutuhan dan analisis kemampuan dengan mempertimbangan analisis SWOT.

Ketika kita berbicara pendidikan berbasis masyarakat maka dengan seharusnya semua tahapan dalam perencanaan sampai dengan evaluasi harus dan wajib mengajak masyarakat. Masyarakat bisa sebagai aktor pelaksana sebagai pengawas dan penilai keberhasilan program. Sehingga diharapkan akan muncul siklus perbaikan berkelanjutan.

\section{Pengorganisasian Pendidikan Berbasis Masyarakat}

Pengorganisasian merupakan langkah selanjutnya setelah perencanaan, pengalokasian keseluruh sumber daya organisasi 
sesuai dengan rencana yang telah dibuat berdasarkan suatu kerangka kerja organisasi tertentu.

Dalam pengorganisasian pada pendidikan berbasis masyarakat tidak berbeda dengan pengorganisasian yang lain. Yang membedakan hanya pendekatan dan basisnya saja. Dalam pengorganisasian dapat dilakukan beberapa tahap sebagai berikut:

a. Pembagian tugas

b. Penetapan relasi antarbagian organisasi

c. Penetapan struktur organisasi

d. Pendelegasian wewenang

e. Dan pengorganisasian( penataan organisasi)

Sudah kita bahas diatas bahwasannya pengorganisasian dalam pendidikan berbasis masyrakat yang membedakan adalah pendekatannya. Yang mana seperti pada perencanaan semua tahapan harus mampu mengakomodir kebutuhan dan keinginan masyarakat

\section{Simpulan}

Desentralisasi dewasa ini menjadi sesuatu yang keharusan diberbagai kalangan. Hal ini karena era demokrasi sudah semakin kental dengan kehidupan berbangsa kita. Dalam teori desentralisasi adalah suatu proses dimana suatu lembaga yang lebih rendah kedudukannya menerima pelimpahan kewenangan untuk melaksanakan segala tugas pelaksanaan pendidikan, termasuk pemanfaatan segala fasilitas yang ada serta penyusunan kebijakan dan pembiayaan.

Dalam dunia pendidikan desentralisasi menjadi angin segar untuk perkembangan bagi pendidikan. Dengan adanya desentralisasi ini pendidikan lebih mempunyai peran dalam mewujudkan tujuan dan cita-cita dunia pendidikan yaitu mensejahterakan seluruh lapisan masyarakat. 


\section{DAFTAR PUSTAKA}

Chan, Sam, Analisis SWOT: Kebijakan Pendidikan Era Otonomi Daerah. Jakarta: PT. Raja Grafindo Persada, 2005.

Daftar Pustaka

Hasbullah, Otonomi Pendidikan. Jakarta: PT Rajagrafindo Persada, 2010.

Ihsan, Fuad, Dasar-dasar Kependidikan, Jakarta: PT Rineka Cipta, 2001.

Imron, Ali, Kebijaksanaan Pendidikan di Indonesia. Malang: Bumi Aksara, 1993.

Nurhattati, Fuad, Manajemen Pendidikan Berbasis Masyarakat Konsep dan Strategi Implementasi, Depok: RajaGrafindo, 2014.

Siti, Irene, Desentralisasi dan Partisipasi Masyarakat dalam Pendidikan. Yogyakarta: Pustaka Pelajar, 2011.

Sudarmanto, Gunawan, Pembiayaan Pendidikan dan Otonomi Sekolah dalam Menghadapi Globalisasi, (t.tp. : t.p.,2010)

Sudarsyah, Asep, "Kerangka Analisis Data Fenomenologi (Contoh Analisis Teks Sebuah Catatan Harian)". Jurnal Pendidikan Vol. 14 No. 1, 2013.

Wangke, Humphrey, Peluang Indonesia Dalam Masyarakat Ekonomi ASEAN, Jakarta:P3DI Sekjend DPR RI, 2009.

Wicaksono, Rohadi, Dunia Pendidikan Di Era Global, t.k: t.p, 2010. 
